\title{
Isaac multiplex: Genesis 22 in a new historical representation
}

\author{
Christo Lombaard ${ }^{1}$ \\ Department of Christian Spirituality, Church History and Missiology \\ University of South Africa
}

\begin{abstract}
In this paper, a new interpretation of the Genesis 22:1-19 account is offered. Based on the new view of biblical historiography as anecdotal (Frykenberg), and drawing on the author's own recent studies on the historical problems related to, and historicallysensitive narratological interpretative possibilities of, this Genesis text, a new meaning and a new dating for Genesis 22:1-19 are concluded to. This text, namely, reflects the end of a struggle for dominance between the different tradents of the patriarchal traditions, in which the Abraham tradents finally subjugate, with this Genesis 22*-text, the Isaac tradents. This occurs late in the compositional history of the Pentateuch, namely between 400 and 250 BCE.
\end{abstract}

\section{ISAAC MULTIPLEX}

As complex as the interpretation history of the Akedah-text, Genesis 22:1-19*, over the past two millennia plus, has been the scholarly analyses of this pericope over the past two centuries plus (see Popović 2002:211-223 for recent bibliographic references). The main redaktionsgeschichtliche and rezeptionsgeschichtliche / wirkungsgeschichtliche lines may briefly be categorised in six different groups:

- Interpretation within the Akedah text, with as prime example the Fortschreibung already in the text as we have it (cf Moberly 1988:302$323)$, namely the almost universally-accepted ${ }^{2}$ editorial addition of Genesis 22:15-18;

\footnotetext{
${ }^{1}$ Paper read at the Society for Biblical Literature International Meeting, Vienna, July 2007.

${ }^{2}$ Van Seters (1975:229); Coats (1983:152); and Seebass (1997:200-201; 213-214) are among the few who differ from the majority on this point.
} 
- The early religious reinterpretations of this narrative within Judaism, Christianity and Islam; ${ }^{3}$

- Representations within art history; ${ }^{4}$

- Within scholarly traditions, the historically-oriented interpretations, about which more below;

- Within scholarly circles still, the narrative approaches to this text, which for our purposes here may be classified with the structuralist and semiotic readings, all of which are interesting, yet rarely offer us something "new", despite a claim to the contrary in the title of many such publications (cf Lombaard 2007b);

- Lastly, philosophical-ethically inclined interpretations, the most famous of which are those by Kierkegaard (1843), Buber (1953) and Derrida (1992), though these discussions certainly go wider, with the best treatment of this interpretational genre the recent paper by Sekine (2007).

In what follows, I remain with the historically-inclined interpretations (for reasons for this choice, see Lombaard 2006a, 2007a, 2007b) of Genesis 1:1$14,19 .{ }^{5}$ This text, it is found, reflects the end of a struggle for dominance between the different tradents of the patriarchal traditions, in which the Abraham tradents finally subjugate, with this Genesis $22^{*}$-text, the Isaac tradents.

\section{A GLIMPSE OF THE PATRIARCHS?}

Usually, when the historical existence or not of the patriarchs are argued, one of three positions is concluded to:

\footnotetext{
${ }^{3}$ Cf e.g. Steiger \& Heinen (2006); Garcia Martínez (2002:44-57); van Bekkum (2002:86-95); Leemhuis (2002:125-139); Bekker \& Nortjé (1995:457-462); Berman (1997); Kruger (1991:190-191).

${ }^{4}$ Cf e.g. Van den Brink (2002:140-151); De Jong (2002:152-165); Berman (1997:137-149).

${ }^{5}$ It is clear that the majority opinion is correct in this instance, that verses $15-18$ are textual additions. This does not mean that these verses are to be disregarded: to the contrary, their effect on recasting the rest of the Akedah-narrative and the resultant effect on the interpretation history of this text are very important, for this study too. My references below to simply "Genesis 22" should be understood as shorthand for Genesis 22:1-14, 19.
} 
- Despite the complexity of the transmission processes from an oral phase to a written phase to redactional activities, ${ }^{6}$ we can glimpse behind these processes still something of the life of an individual figure from whom originated, even if just as a kernel, these traditions. The figure of the patriarch is, albeit vague and distant, a historical given.

- Both the texts themselves and the complexity of the transmission processes just referred to prevent us from making any firm deductions about the existence or not of the patriarch concerned. Yet, based on the contents of the texts and, frequently, their placement within the Pentateuch, we can at least find some socio-cultural material deposited in them, within which a patriarchal figure might have existed.

- The contradictions between the respective patriarchal texts, among other difficulties with them, as well as the complexity of the transmission processes, make it impossible to say that these texts attest to any historical reality in the form of a patriarch, except as a literary creation. There was no real patriarch. There was, however, a figment or some sort, a literary imagination, the purposes of the creation of which are open to historical investigation.

All three these positions, however, still simplify what is clearly a most complex situation. While any one of these three options may to some extent be correct in some instances, none would apply to all cases. The reason for this is that the assumption is often shared that the traditions relating to a certain patriarch - say, Isaac - refer to an Isaac. I hold the view, however, that all of the patriarchs are composite figures. Even if it could be said that the Isaac traditions refer to a historical ancestor Isaac, I would argue that they do not refer to the same individual. An identical position could be taken on traditions related to patriarch Isaac as a purely literary creation: the diversity of Isaac passages do not enable us to link them together to come to a broad vision of the shared figure of "Isaac". More accurately, one would always have to refer to this composite or multiplex character in the plural, as "Isaacs".

The move we have seen in recent decades away from the minute exegetical analyses of texts to the greater compositional corpora, have enticed us to look past the fact that all historiography in the Pentateuch is episodic too. Pericopae form - following here Frykenberg (2001:116-137) -

\footnotetext{
${ }^{6}$ See Schniedewind (2004:3-23) for a recent discussion of the writing/editing process.
} 
a valid anecdotal unit). ${ }^{7}$ This does not mean that looking either at the minutiae of texts (text-critical aspects, for instance) or at the broad compositional layers (such as, currently popular, $P$ and non-P), is in any sense unimportant. However, in both cases we may, having completed these analyses, be led to assume that all the Isaac stories we have encountered denote the same referent (either as an actual historical person or as a literary character). ${ }^{8} \mathrm{My}$ contention is that all the patriarchs are multiplex figures, referring to different antecedents. Therefore, neither the relevant textual occurrences, nor within each of those, the different literary or compositional layers, may be assumed to relate to the same underlying "idea" of Isaac, for instance. Rather, a "next identity", a new composite identity, is created by each end product; this, then, is another Isaac, and not one that can now without further consideration be read back into any one or across all of the constituent Isaac texts. ${ }^{9}$

This approach opens up some new interpretative possibilities. Genesis 22 (Abraham's almost-sacrifice of Isaac) may serve as an example.

\section{GENESIS 22 IN HISTORICAL INTERPRETATIONS, RELATED}

The historically-oriented interpretations of the meaning of the Genesis 22account ${ }^{10}$ may be divided, broadly, into two main streams: ${ }^{11}$

\footnotetext{
${ }^{7}$ Though I agree with their underlying understanding of the nature of historiography, I do not use this term as does Gunn \& Fewell (1993:6), in their sense as something historically more reliable than sagas, legends and novellas in the Old Testament, categories which they view negatively. Rather, linking up with the philosophy of history of e.g. Frykenberg (2001:116-137), my view here is that, at least as far as the Pentateuchal accounts are concerned, there is value in also regarding each text/pericope/account as a text in itself, with its links to other texts a different matter, which is to be considered critically.

${ }^{8}$ The decision on this matter dare not be generalised either; rather, each anecdotal unit should be evaluated in itself, before deductions are made about the whole of the Abraham cycle, for instance. This is an operational modus which is quite at home within classical tradition history.

${ }^{9}$ This argument thus runs in some ways parallel to Davies's (1992) on "Israel" In search of ancient Israel (1995), though here in some sense filtered through Albertz's religionsgeschichtliche approach. Of course, it would be valid to understand texts as they are reinterpreted in the newly-cast light, for instance to understand Genesis 22:1-14 \& 19 in the light of the reinterpretation offered in Genesis 22:15-18, or to rethink all the Abraham-Isaac texts in the light of Genesis 22, dated late. That would be to follow the thinking proposed by the later editor. However, the text(s) as understood before the recasting of meaning by this later editor is an equally valid object of investigation, as its own anecdotal unit. It is on this last aspect that all approaches which stress the "final text" or "canonical text" falter: they simply buy into the ideas of whichever editor happened to have a hand in last.

${ }^{10}$ For an overview of the historical questions which have been raised in relation to the Genesis 22 -text, see Lombaard 2007c.

${ }^{11}$ Two minor streams offer alternative historical interpretations: that the Genesis 22-account reflects an earlier aetiology of the name of the mountain in 22:14 (יהונה יר: יראה:), and that Genesis 22 reflects an initiation rite (only White 1991:187, 203, drawing on his earlier work, White 1979:1-30). Though some vague nods have been made in the direction of the former proposal, though always with the qualification that even if it were true, that aspect now lies so far behind the text as to be essentially untraceable, the White-suggestion has found no audience.
} 
- those that seek to understand the text within the cultic history of ancient Israel; and

- those that understand the text within the theodicy discussion among Old Testament texts.

Genesis 22 placed within the cultic history of Israel sees behind the text the ancient practice of child sacrifice, with this text seeking to put to an end such practices, by indicating God's choice of, rather, an animal. The fact that this prohibition is placed by the Genesis 22 narrative at the very beginnings of Israel's faith history, namely with the arch-patriarch Abraham, is intended to show to the intended audience of this text that from the father of their Yahweh-belief onwards (as they understood its construction in the post-exilic time), child sacrifice had been anathema.

The dating attached to the Genesis 22-narrative by proponents of this solution varies quite widely, from after 722/721 (so, recently, Noort 2002:19), to the time of king Manasseh (because of the reference to child sacrifice in 2 $\mathrm{Ki} 21: 6$, and usually as part of the Elohist's $7^{\text {th }}$ century narrative; cf e.g. Steins 2001:514-515), to shortly after the exile (the most popular suggestion at present), to - in the case of Stavrakopoulou 2004 - much later in Israel's history, since child sacrifice would have, according to Stavrakopoulou, continued as a part of Israel's practice of faith.

With Genesis 22 understood as a text within the clearly post-exilic theodicy controversy, this account finds itself among texts such as Job (a very popular linkage made in scholarly literature; see e.g. van Ruiten 2002:58-85) and Qohelet, reacting against, for instance, some Proverbs-texts which, with the most observable connection to Deuteronomistic theology, advocate a firm retributive ethical order. Against the latter, Genesis 22 points to the mystery of God's ways. In the exilic/post-exilic period, while coming to terms with 587/6, Genesis 22 would then be another representative of post-dogmatic piety within Israel. Genesis 22 would argue in this debate that suffering, leading almost to death, and from which there is, after all, escape, are all part of the inscrutability of God's ways with Judah.

In the first of these two major historically-oriented interpretations, a preor early-Yahwistic element (though probably not a non-Yahwistic element) of Israel's faith, namely child sacrifice, is countered by Genesis 22; in the second such interpretation, a post-exilic ethical dogmatism is opposed. Both these interpretations have found common expression within the historically-inclined exegeses of the Genesis 22-text; however, among the synchronic interpretations, it is mostly an interpretation building on the latter that has 
found favour. Either dehistoricised or read simply as a historically accurate account (cf Lombaard 2007b), Genesis 22 becomes in this line of thinking an exhortation to faith in all circumstances; that is, encouragement to trust that God will provide an escape from difficult situations, even though these cannot always be foreseen by human parties. Genesis 22 is thus a pious, moral tale. However, the morality of a God that in fact created the almost-slaughter of Isaac in this narrative is left unconsidered by such readings (and usually by those within the historical line of exegesis, when this interpretation is offered, too), rendering such explanations wholly unfit to provide the model of trust they seek to impart. This is precisely the kind of weaknesses missionary antireligious writings, such as those by Dawkins (2006:242-243) recently again, have focussed on. Such narrow moralistic interpretations of Genesis 22 will not change, nor certainly answer, the questions popularly asked about this text (Lombaard 2007c). Neither can the philosophically-oriented discussions, which tend to offer conjectures on concepts and themes in this account interesting enough, but not resolving much. It remains with historical exegesis to open avenues of accounting for the existence of this text and its inclusion in the canon. It is along these lines that another historical context for this account is now proposed.

\section{GENESIS 22 AND THE RELATIONSHIP BETWEEN THE PATRIARCHS}

This proposed alternate historical understanding of Genesis 22 was induced by the text-as-anecdotal-history view indicated above. In this reading, Genesis 22 retains the familiar themes: threat, saving grace, and subjugation; now, however, not related to either religious practice or to theological debate, as had been the case with the respective historical explanations summarised above, but related to inner-Israelite identity politics. Genesis 22 can namely be read as a text reflecting the power play within ancient Israel/Judah, in which the carriers of the Abraham traditions with this narrative either reflect on past events, or threaten imminent events, in their conflict with the carriers of the Isaac traditions.

It has for a long time been clear to historical scholarship from parallel

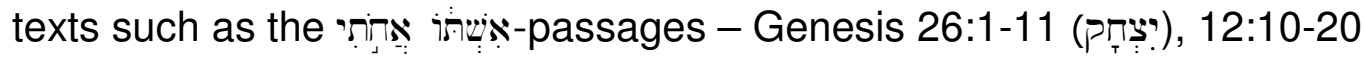

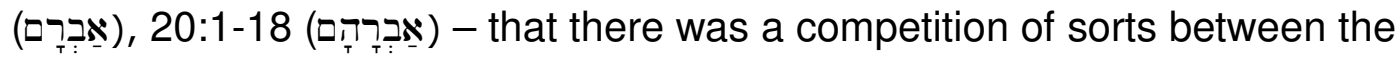
respective tradents of the Isaac and Abraham traditions in ancient Israel. By the sheer weight of Abraham-texts included in the Pentateuch when compared to the few lsaac texts, it is clear who the winner in this power

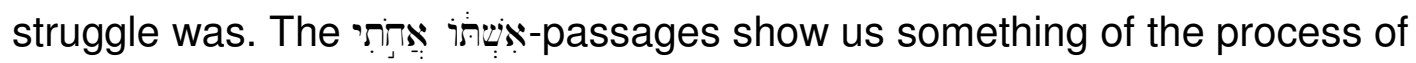


this rivalry. The one whose stories dominate, dominate history - and vice versa.

Following this line of interpretation, in Genesis 22 we find Isaac, and thus per implication the Isaac tradents, at the mercy of both Abraham and God, and so per implication at the mercy of the Abraham tradents. ${ }^{12}$ Isaac is cast in the role of family idiot: he has no inkling of what is about to happen. Isaac (and so the Isaacites) is in the power of Abraham (Abrahamites) and God: the latter two form a powerful union in which Isaac (the Isaacites) is both clueless and powerless. The warning is clear: Isaac (the Isaacites) will from now on play a subservient role in the religious identity of the composite "tribe"

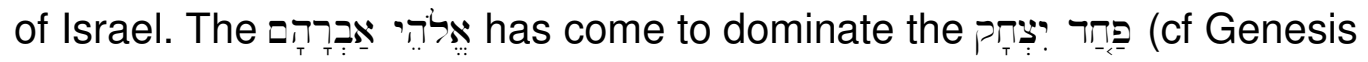
$31: 42 \& 53) ;^{13}$ the union of Israel, post-exilic, is being forged with power, that is, with both the threat of demise and with divine justification/compliance. Such power-rhetoric is typical of ruthless "political scheming" (this terminology from Kruger 1991:193): that the threat of violence is combined with theological support. This is a claim which is always easy for a dominant group to make, and always almost impossible for the dominated to refute. The Isaacites in Israel have been overpowered by the Abrahamites. Isaac now fully plays the role of an insignificant middle child. To recontextualise the words of White (1991:190): "His role and identity thus are defined altogether with respect to the powerful bonds which tie him to Abraham", and, I would add, to the alliance with God which Abraham claims.

Thus, Genesis 22 here plays a role in some ways parallel to that which had been ascribed to Joshua 24 in the amphictyony theory of Noth (1954:83104 ), namely that we see in this text different groups being combined, if not unified; in this case, though ultimately peacefully, not without the threat of imminent, divine-sanctioned violence. It is but by the grace of God that Isaac lives; had it been in the hands of Abraham, Isaac would be no more - this is clearly the implication the Isaacites should grasp. ${ }^{14}$

\footnotetext{
12 Unintentionally, Von Rad (1976:194) comes very close to this view, when he writes: "Das spätere Israel ... konnte wohl nichts anders als sich in Isaac verkörpert zu sehen, d.h. also auf den Altar Jahwes gelegt, ihm zurückgegeben und dann allein von ihm das Leben zurückempfangend, ... allein aus dem Willen dessen, der Isaac aus der Freiheit seines Geschichtswillen leben ließ."

${ }^{13}$ Clearly, Alt's (1929) Gott der Väter-hypothesis echoes here ...

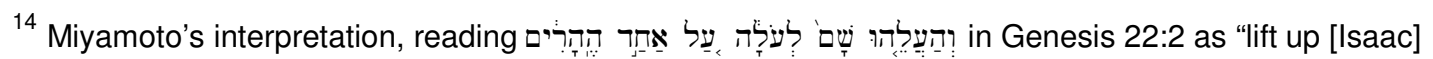
on the mountain in order to offer a burnt offering" (cf Sekine 2007:11 on Miyamoto 2006:81-162) may be creative, and his resultant conclusion that Genesis 22 leads to "a tribe-conquering narrative identity" Sekine (2007:11) appears attractive to my proposed interpretation here. However, Miyamoto apparently indicates a personal, existential element with this phrase, whereas the interpretation possibility offered here is that an adversarial relationship between two different tradent groups, which is "resolved" by the one now finally and thoroughly coming to dominate the other, "with God on our side" (in the words of folk singer Bob Dylan 1964).
} 


\subsection{Genesis 22:19}

The two problems of Genesis 22:19, that Abraham returns from the mountain alone, and that he then goes to Beersheba, may be resolved differently from the usual suggestions with this interpretation. The Abraham-alone reference is not a simple pars pro toto expression here, referring to only Abraham but implying that Isaac went along; nor is this the point where Isaac finds his own way, his own identity apart from Abraham. Rather, the opposite is true: Isaac counts no more; the Isaacites have been subjugated. It is therefore not without good reason that it is for, precisely, Beersheba, the home base of the Isaac traditions, that Abraham then departs. The geographical reference is not meant as a narrative link of this account to the out-of-place episode of the treatise between Abraham and Abimelech which immediately precedes Genesis 22 (i.e. Gn 21:25-33; 34; at best, the shared geographic reference may explain why these two texts were put next to one another by later editor/s). Beersheba too is now Abraham's domain. The Isaacites have been vanquished; the winner takes all.

\subsection{Genesis 22:15-18 \& 1}

Soon, a sugar-coating was needed. When power-play has succeeded, it can be hidden, so that the powerful may be experienced (again) as "good people". This not only portrays the winner who took all in a more positive light; it also stabilises the power relation which has been established. The act of subjugation is sublimated. Thus, with theological flair, Genesis 22:15-18, does both: it gives new credence to the acts of Abraham (and thus the Abrahamites) by making him "ein religiöses Ideal" (Gunkel 1917:240), ${ }^{15}$ rewarded in these verses by God's by blessing; this is done in such a way that Isaac (the Isaacites) suffer(s) the inconsequence of instrumentalist reference only: for him/them, no reward, ${ }^{16}$ except perhaps to count among those who are blessed in the arch-patriarch $(22: 18) .{ }^{17}$

\footnotetext{
${ }^{15}$ Boehm (2002:1-12; 2004:155-156) thinks in some ways along parallel lines to my reasoning on this point, but sees the heavenly intervention here as a later apology for Abraham who, in an older version of the events, sacrificed a sheep in stead of obeying the command of verse 1 . He accepts, thus, concord between Abraham and Isaac - one of many such apologetic turns in both the academic and religious literature on the Akedah. An interpretation which notices the inner-religious contest, however, requires no such interpretative turns.

${ }^{16}$ The harmonious interpretation of this narrative as that Abraham and Isaac are here given to one another, because of their shared obedience to God, as Kaiser (2003:224) would have it, does not take into account the minute, instrumentalist-only role Isaac is afforded here. In addition, one has to make sense of the given that Isaac is absent from verse 19, and Abraham moves alone to Beersheba, the home of the Isaac traditions, symbolically with this narrative to take over both the place and to some extent the Isaac traditions. The latter we see most clearly with the "my wife my sister" passages.

${ }^{17}$ Moberly's interpretation (1988:319-323) of the verses 15-18 addition, namely that Abraham would from now on (i.e. for Moberly, the $7^{\text {th }}$ or $6^{\text {th }}$ century) play an intercessionary role in Israel's faith, would have supported my argument here: Isaac is rendered powerless by God-and-Abraham-in-cahoots. However, I do not find this Abraham-as-intercessionary view of the Akedah-postscript by Moberly convincing.
} 
This earliest reinterpretation was cemented by employing the term tempting/testing/trying) in Genesis 22:1 (cf Gunkel 1917:238). Thus, the whole account is now recast, from the beginning, giving it with a much stronger theological than political slant. From this instant onwards (in both the narrative and its reception history), the story is all about God and Abraham (reinterpreting Westermann 1981:434, 436); the overpowering of Isaac is overlaid with a theological motif. Of course, as happens with so much political interference in matters religious, the results could not be foreseen: 24 centuries - and counting - of speculation on what could have been going on in God's mind ...

\subsection{4 centuries ...?}

The dating of this text, as with so many others, is in the by now stock phrase, notoriously difficult. Despite my misgivings about the possibilities narratology offers with the interpretation of the meaning of this text, I hold higher hopes on the promise it holds for dating Genesis 22 - if properly done. As I argued earlier (Lombaard 2007b):

(N)arrative analyses do not go far enough. The story may be retold, beautifully even, but what is offered us, in the end, is primarily a phenomenology of that particular narrative. Such a study ... is not full narrative criticism yet. Telling us how the narrative works, is only step one... Full narrative analyses of the Bible would now take a next step, and discern trends in writing, comparing the art of the narrative in different historical phases and socio-cultural contexts, which is among the standard procedures of the scholarly critique of literature in general. This step, which would be so helpful, is never undertaken in narrative analyses of the biblical literature.

The question to ask of Genesis 22, thus, is: when is the time of the short story in ancient Israel? In classical Pentateuchal Literarkritik, the time of "the great narratives" (to appropriate Lyotard 1989:315) began with a Solomonic J, perhaps around 950. Now, much less impressive ages for a $\mathrm{J}$ are commonly accepted; yet, the point remains that Literarkritik / Literargeschichte and Literaturkritik / Literaturgeschichte are not that far removed from one another. On the less expansive though perhaps more coherent narratives, such as first Daniel and then Joseph, the accorded age has dropped equally dramatically, as the "carbon dating" of critical scholarship has continually been applied. For 
the most part, the "short stories" such as the books of Esther, Jonah and Ruth have long found a comfortable consensual home in post-exilic to late-postexilic times. For a narrative such as Genesis 22 to be placed within the fourth century (or third?) is therefore a possibility not to be reckoned without, given that the literary genre of the short story finds an easy home in this period.

This would not mean that this is the first time any hint of this story-tocome had existed. The possibilities of an aetiology (22:14), an intra-religious polemic about child sacrifice, and a theodicy debate, all of which may have in some ways given impetus to what became "our" story, are not to be discarded. All stories draw significantly, though not necessarily deliberately, on themes and ideas available within their birth culture - cultural "reverberations", in the language of Boehm (2004:147).

It is for precisely this reason, namely that the theme of child sacrifice becomes more acceptable at some distance from the exile and the strongest influence of Deuteronomistic theology, that a later dating for Genesis 22 is more likely than an earlier dating. It seems unlikely that child sacrifice would have survived as actual practice in the Judean cult past the exile, or even past the prophets such as Hosea and Amos, simply because of the ethical impulses towards social justice from these prophets onwards. (That is, if actual child sacrifice had been a significant part of Yahwism at all, or of the surrounding religions, about which doubts have been expressed.) The point is, however, that after the initially conservative stances post-exilically we find in particularly Ezra-Nehemiah, the reacting outward-looking stances in Judea tend to be more positive towards contact with outside cultures. Thus, Ruth goes to Moab, probably in the $5^{\text {th }}$ century; Jonah to Nineveh, in the late $4^{\text {th }}$ / early $3^{\text {rd }}$ century; and Esther to Persia, during the $3^{\text {rd }}$ century; the wisdombook Qohelet goes so far as to quote, both with approval and in dispute, Hellenistic philosophy, in the $3^{\text {rd }}$ century (cf Lohfink 2003). A growing openness can thus be detected in this cultural phase in Judaism towards employing "external" elements in order to make an "internal" point. The use of a theme from the religious environs of Yahwism, such as child sacrifice, would thus fit well with a later dating of the Genesis 22-narrative.

Based on these two considerations - literature type (the prominence of the short story in Israel) and thematic orientation (the easier acceptance of "foreign" material) - the Akedah could be dated with some certainly no earlier than the fourth century, though precisely how long after 400 remains unclear. The earliest reinterpretation of the story, by means of the new frame of verses 22:15-18 \& 1, as indicated above, could have occurred within a very short period of time; precision, though, eludes everybody on this point. The latest possible dating for the text as a whole would be around 280-250 (cf e.g. Dines 
2004:41-45), with the translation of the Hebrew Bible texts into Greek, that is, into the Septuagint.

\subsection{The remains of the day}

With this theory proposed, what remains to investigate is how the subjugation of Isaac in Genesis 22 is effected in the rest of the Isaac narratives; that is, how this "new Abraham" and "new Isaac" colour anew the other Old Testament references. Genesis 22 could thus indeed become a "centre" of sorts of the Pentateuch (as Steins 2001:516 would have it, but differently understood here). Such following investigations would not only provide further critical reflection on the possibilities, or none, this suggested interpretation offers, but could also aid in the relative dating of the Isaac and related texts.

\section{Works consulted}

Albertz, R 1992. Religionsgeschichte Israels in alttestamentlicher Zeit, 1. Göttingen: Vandenhoeck \& Ruprecht. (Grundrisse zum Alten Testament, Ergänzungsreihen, ATD Band 8/1.)

Alt, A 1929. Der Gott der Väter: Ein Beitrag zur Vorgeschichte der Israelitischen Religion. Stuttgart: Kohlhammer. (BWANT 3/12.)

Bekker, C J \& Nortjé, S J 1995. Die gebruik van die offer van Isak as 'n motief vir die verkondiging van Jesus as die lydende Christus. HTS 51(2), 454-464.

Berman, L A 1997. The Akedah: The binding of Isaac. Northwale: Jason Aronson.

Boehm, O 2004. Child sacrifice, ethical responsibility and the existence of the people of Israel. Vetus Testamentum 54(2), 145-156.

Boehm, O 2002. The binding of Isaac: An inner-Biblical polemic on the question of "disobeying" a manifestly illegal order. Vetus Testamentum 52(1), 1-12.

Buber, M 1953. Gottesfinsternis: Betrachtungen zur Beziehung zwischen Religion und Philosophie. Zürich: Manesse Verlag.

Coats, G W 1983. Genesis, with an introduction to narrative literature. Grand Rapids, MI: Eerdmans. (The Forms of Old Testament Literature, Vol 1.)

Davies, P R 1995. In search of "ancient Israel", 2nd edition. Sheffield: Sheffield Academic Press.

Dawkins, R 2006. The God delusion. London: Bantam.

De Jong, J L 2002. Three Italian sacrifices: Lorenzo Ghiberti, Andrea Del Sarto, Michelangelo Merisi Da Caraveggio, in Noort, E \& Tigchelaar, E (eds), The sacrifice of Isaac: The Aqedah (Genesis 22) and its interpretations, 152-165. Leiden: Brill.

Derrida, J 1992. Donner la mort, in L'Éthique du don. Paris: A M Métailié.

Dines, J M 2004. The Septuagint. London: T \& T Clark.

Frykenberg, R E 2001. Anecdote as the essence of historical understanding, in Yandell, K E (ed), Faith and narrative, 116-137 Oxford: Oxford University Press. 
Garcia Martínez, F 2002. The sacrifice of Isaac in 4Q225, in Noort, E \& Tigchelaar, E (eds), The sacrifice of Isaac: The Aqedah (Genesis 22) and its interpretations, 44-57. Leiden: Brill.

Gunkel, H 1917. Genesis. 4. Auflage. Göttingen: Vandenhoeck \& Ruprecht. (Göttinger Handkommentar zum Alten Testament.)

Gunn, D M \& Fewell, D N 1993. Narrative in the Hebrew Bible. Oxford: Oxford University Press.

Kaiser, O 2003. Die Bindung Isaacs, in Kaiser, O (Hrsg), Zwischen Athen und Jerusalem: Studien zur griechischen und biblischen Theologie, ihrer Eigenart und ihrem Verhailtnis, 199-224. Berlin: De Gruyter.

Kierkegaard, S (= de Silentio, J) 1843. Frygt og Bœven: Dialektisk Lyrik.

Kruger, H A J 1991. God tests Abraham: The command to sacrifice Isaac. NGTT 32(2), 187-200.

Leemhuis, F 2002. Ibrāhīm's sacrifice of his son in the early post-Koranic tradition, in Noort, E \& Tigchelaar, E (eds), The sacrifice of Isaac: The Aqedah (Genesis 22) and its interpretations, 125-139. Leiden: Brill.

Lohfink, N 2003. Qohelet: A continental commentary, tr by S McEvenue. Minneapolis, MN: Fortress.

Lombaard, C 2006a. The Old Testament between diachrony and synchrony: two reasons for favouring the former. Journal for Semitics/Tyskrif vir Semitistiek 15(1), 18-31.

Lombaard, C 2007a. The Old Testament between diachrony and synchrony: two reasons for favouring the former, in Le Roux, J \& Otto, E (eds), The

Pentateuch between synchrony and diachrony, 61-70. New York: T \& T Clark.

Lombaard, C 2007b. Problems of narratological analyses of Genesis 22:1-19*. Paper read at the congress of the International Organisation for the Study of the Old Testament, Ljubljana, Slovenia, July 2007. To be published in the upcoming IOSOT congress volume in the series Beiträge zur Erforschung des alten Testaments und des antiken Judentums, edited by Augustin, M \& Niemann, $\mathrm{H}$ $\mathrm{M}$.

Lombaard, C 2007c. What are the historical issues in Genesis 22? Paper presented: ProPent conference, Munich, July 2007. Publication upcoming.

Lyotard, J-F 1989. Universal history and cultural differences, tr by D Macey, in Benjamin, A (ed), 314-323. The Lyotard Reader. Oxford: Basil Blackwell.

Miyamoto, H 2006. Aburahamu no junan to tasha no chihei - Hyōhaku no monogatari kara hayatorogia (heburaiteki sonzairon) teki kyōsei (= The suffering of Abraham and the horizon of the Other - from bleached narrative to hayatological (Hebraic ontology) symbiosis), in Miyamoto, $\mathrm{H}$, Onuki, T \& Yamamoto, T (eds), Junan no imi: Aburahamu, lesu, Pauro ( = The meaning of suffering: Abraham, Jesus, and Paul), 81-162. Tokyo: Tokyo University Press ${ }^{19}$.

Moberly, R W L 1988. The earliest commentary on the Akedah. Vetus Testamentum 38(3), 302-323.

\footnotetext{
${ }^{19}$ With thanks to Seizo Sekine for the translations and references.
} 
Noort, E 2002. Genesis 22: Human sacrifice and theology in the Hebrew Bible, in Noort, E \& Tigchelaar, E (eds), The sacrifice of Isaac: The Aqedah (Genesis 22) and its interpretations, 1-20. Leiden: Brill.

Noth, M 1954. Geschichte Israels. Zweite, verbesserte Auflage. Göttingen: Vandenhoeck \& Ruprecht.

Popović, M 2002. Bibliography of recent studies, in Noort, E \& Tigchelaar, E (eds), The sacrifice of Isaac: The Aqedah (Genesis 22) and its interpretations, 211223. Leiden: Brill.

Schniedewind, W M 2004. How the Bible became a book: The textualization of ancient Israel. Cambridge: Cambridge University Press.

Seebass, H 1997. Vätergeschichte I (11, 27-22, 24). Neukirchen-Vluyn: Neukirchener Verlag.

Sekine, S 2007. Philosophical interpretations of the sacrifice of Isaac. Paper read at the congress of the International Organisation for the Study of the Old Testament, Ljubljana, Slovenia, July 2007.

Stavrakopoulou, F 2004. King Manasseh and child sacrifice: Biblical distortions of historical realities. Berlin: De Gruyter.

Steiger, J A \& Heinen, U (Hrsg) 2006. Isaaks Opferung (Gen 22) in den Konfessionen und Medien der Frühen Neuziet. Berin: De Gruyter.

Steins, G 2001. Die Versuching Abrahams (Gen 22.1-19): Ein neuer Versuch, in Wénin, A (ed), , 509-519. Studies in the book of Genesis: Literature, redaction and history. Leuven: Uitgeverij Peeters.

Van Bekkum, W J 2002. The Aqedah and its interpretations in midrash and piyyut, in Noort, E \& Tigchelaar, E (eds), The sacrifice of Isaac: The Aqedah (Genesis 22) and its interpretations, 86-95. Leiden: Brill.

Van den Brink, E 2002. Abraham's sacrifice in early Jewish and early Christian art, in Noort, E \& Tigchelaar, E (eds), 140-151. The sacrifice of Isaac: The Aqedah (Genesis 22) and its interpretations. Leiden: Brill.

Van Ruiten, J T A G M 2002. Abraham, Job and the book of Jubilees: The intertextual relationship of Genesis 22:1-19, Job 1-2:12 and Jubilees 17:1518:19, in Noort, E \& Tigchelaar, E (eds), The sacrifice of Isaac: The Aqedah (Genesis 22) and its interpretations, 58-85. Leiden: Brill,

Van Seters, J 1975. Abraham in history and tradition. New Haven: Yale University Press.

Von Rad, G 1976. Der Erste Buch Mose: Genesis. 10., durchgesehene Auflage. Göttingen: Vandenhoeck \& Ruprecht. (Das Alte Testament Deutsch.)

Westermann, C 1981. Genesis, 2. Teilband: Genesis 12-26. Neukirchen-Vluyn: Neukirchener Verlag.

White, H C 1991. Narration and discourse in the book of Genesis. Cambridge: Cambridge University Press.

White, H C 1979. The initiation legend of Isaac. ZAW 91, 1-30. 